International Journal of Physical Sciences and Engineering
Available online at http://sciencescholar.us/journal/index.php/ijpse
Vol. 3 No. 2, August 2019, pages: $1 \sim 11$
e-ISSN : 2550-6943, p-ISSN : 2550-6951
https://doi.org/10.29332/ijpse.v3n2.285

\title{
Design of Eco-Friendly Refrigeration System
}

\author{
(1) corssiant

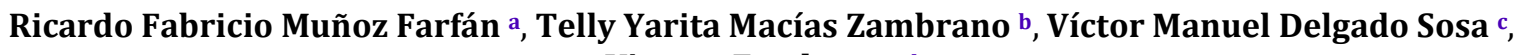 \\ Vicente Zambrano ${ }^{\mathrm{d}}$
}

Article history: Received 27 December 2018, Accepted: 30 April 2019, Published: 14 May 2019

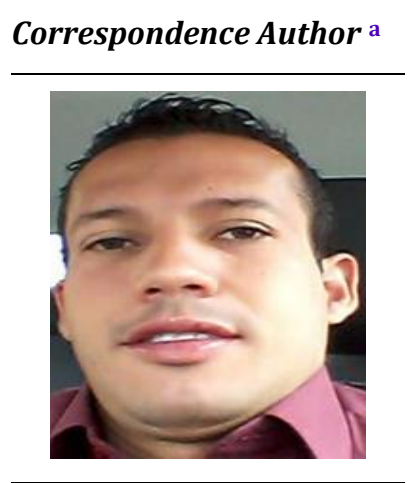

Keywords

freezing; installed capacity;

PID;

$R 22$ gas;

temperature;

\begin{abstract}
The present study of a freezing system has developed based on an air conditioning system, whose purpose is to take advantage of the technological transfer of cold producing equipment for food storage and conservation uses. The installed capacity of $9000 \mathrm{BTU} / \mathrm{Hr}$ was considered for the choice of equipment. We studied the freezing process of fish, water, and the preservation of legumes with a volume of $1 \mathrm{~kg}$ per product individually. The freezing temperature has evaluated with a mechanical compression refrigeration system of Gas R22 with temperature interactions of $29.6^{\circ} \mathrm{C}$ to $-12^{\circ} \mathrm{C}$. and monitored with a Proportional Integrative Derivative (PID) controller. For production cost, the equipment was mostly made of its parts and pieces with recycling material. A descriptive experimental design has carried out, for the verification of results. The equipment managed to reach chamber temperatures of $-13^{\circ} \mathrm{C}$ from 20 minutes once the equipment (compressor) has turned on under specific product descriptions.
\end{abstract}

e-ISSN: 2550-6943, p-ISSN: 2550-6951 ๑Copyright 2019. The Author. SS Journals Published by Universidad Técnica de Manabí. This is an open-access article under the CC BY-SA 4.0 license (https://creativecommons.org/licenses/by-sa/4.0/) All rights reserved.

\section{Contents}

Abstract

1. Introduction

2. Materials and Methods

3. Results and Discussions

4. Conclusion Acknowledgements

a Higher Technological Institute Paulo Emilio Macias, Portoviejo, Manabí, Ecuador

b Higher Technological Institute Paulo Emilio Macias, Portoviejo, Manabí, Ecuador

c Higher Technological Institute Paulo Emilio Macias, Portoviejo, Manabí, Ecuador

d Higher Technological Institute Paulo Emilio Macias, Portoviejo, Manabí, Ecuador 


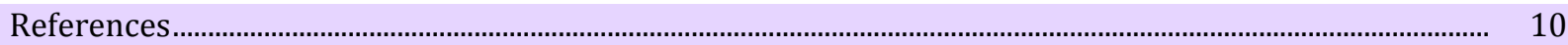

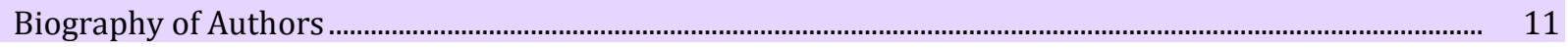

\section{Introduction}

Socioeconomic growth in Ecuador through the transformation of the productive matrix has been one of the priorities of the State regarding its public policies, in this section the repowering of productivity from various socio-productive approaches, together with the Human Talent that the Institutions of Higher Education (IES) contribute directly with their careers at the technological level, guaranteeing interesting proposals for entrepreneurship at the service of society (National Assembly, 2013).

At an international level, the production sector has experienced growth in different fields and services, such as food preservation products, without a doubt is the path of development and entrepreneurship to the increase in productivity and technological insertion at a general level.

In Ecuador there is a $60 \%$ of the manufacturing production dedicated to Refrigeration processes and conservation of products such as dairy products, seafood, fish, vegetables, ice cream among others, which involves a process of refrigeration and freezing, which results in the relevance of develop cold chambers with an innovative component and with technological transfer at a good cost-benefit, both economic and sustainable with the environment, which articulates the objectives 7, 8, 10 and that from the contribution of HEIs in the strengthening of capacities and potentialities of human talent in such a way to promote the dynamic interaction with the productive sector and the link of scientific research with the technological component in favor of the transformation of the productive matrix in order to boost national quality production with emphasis on the prioritized sectors (National Assembly, 2013).

On the other hand, with the manufacture of these cold producing equipment with disused materials, it is promoted in the collection and selection of recycling materials, preventing and mitigating environmental contamination in production and consumption processes, complying with social responsibility practices and environmental. In view of the aforementioned, the preparation of freezing equipment through an installed base of knowledge and disused materials is proposed as a feasible measure for the development of entrepreneurship and contribution to the care of the environment by using recycling products (Ghosh, 2017; Belvinel et al., 2018; Omer, 2015).

Likewise, the proposal to elaborate teams of this kind will contribute to consolidating a social and solidarity economic system, in a sustainable manner in the creation of mini entrepreneurial enterprises of knowledge and production, and which is closely linked with the transition to the change of productive matrix Strengthen the economy of small and medium enterprises, developing innovative capacity, promote scientific and technological development, to improve diversification and inclusion levels and commercial production competitiveness. On the other hand, the importance of designing freezing systems in the region due to its subtropical, dry to the humid and tropical extremely humid tropical environment is determined by marine currents, the average temperature inPortoviejois $25^{\circ}$ Cand in the city, Blanket $23.8^{\circ}$

\section{Materials and Methods}

The present investigation was developed in the city of Portoviejo - Manabí - Ecuador position $341^{\circ} \mathrm{N}$, $170 \mathrm{ft}$ height, $1 \mathrm{~atm}$. Atmospheric pressure; at the facilities of the Paulo Emilio Macías Higher Technological Institute, with an experimental design based on several tests of variable interval testing, applied to a refrigeration system, proposed as an alternative of sustainable eco-technology transfer that is to be achieved from environmental temperatures of $29^{\circ} \mathrm{C}$ to $-13^{\circ} \mathrm{C}$. To achieve this objective, the materials shown were selected in the Table 1. 
Table 1

Materials and equipment for the preparation of the freezing system

\begin{tabular}{lc}
\hline Materials / Equipment & Quantity \\
\hline HVAC equipment & 1 \\
Copper pipes 3/4 & $2 \mathrm{mtrs}$ \\
Iron angles 1/8 XL & $12 \mathrm{mtrs}$ \\
Paintanticorrosive white & $1 \mathrm{ltr}$. \\
6011electrode & $1 \mathrm{lbr}$. \\
discharge valves and measuring & $2 \mathrm{pcs}$ \\
pressure & \\
galvanized plates measures: & $2 \mathrm{Irons}$ \\
Gas refrigerant R22 & $2 \mathrm{Kg}$. \\
PID controller TC-900Log & $1 \mathrm{Unid}$. \\
Rubber sealing door & $4 \mathrm{mtrs}$. \\
thermal insulation (louvered) & $1 \mathrm{~m} 3$ \\
\hline
\end{tabular}

\section{Results and Discussions}

\section{Description of the cooling system}

The cold room is of modular type with the low-temperature application of less than $13^{\circ} \mathrm{C}$ with internal dimensions of $0.8 \mathrm{~m}^{3}$ of internal chamber volume, in figure 1 , shows the internal view of the camera (A) and in (B) the rear view.
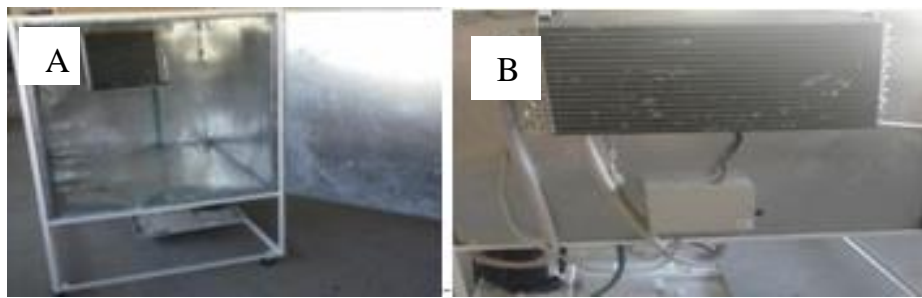

Figure 1. Internal view - cold-evaporator chamber (A), Rear view cold-condenser chamber (B)

The mechanical compression system will have the capacity of $9000 \mathrm{Btu} / \mathrm{hr}$, with its equivalences of 2267 $\mathrm{Kcal} / \mathrm{hr}, 2,636 \mathrm{kWh}, 2636 \mathrm{~W} / \mathrm{h}, 2267$ frig / h, $9450 \mathrm{KJ} / \mathrm{h}$; a PID controller PID TC-900E (www.fullgauge.com, sf) Log (proportional, Integrative and Derivative) for the control and efficiency of the equipment to reach optimal temperatures for frozen, automates the processes of defrosting according to the need of the installation (thaw intelligent), providing energy savings. It acts with 2 main sensors, one for room temperature and another one, fixed in the evaporator, controls the end of the defrosting and the return of the fans.

Structurally worked with galvanized sheet materials manufactured under ASTM A653G40 of $1.4 \mathrm{~mm}$ thickness, its dimensions are $1220 \mathrm{~mm}$ wide by $2440 \mathrm{~mm}$ long and iron angles $3.2 \mathrm{~mm}$ thick (Mittal, sf), as chassis of support both of camera and of mechanical equipment and electrical and electronic connections; likewise, the structure will be joined with deposit of electrode material E 6011 (deep penetration cellulose electrode) applied in electric welding. Insulating materials such as expanded polystyrene with a heat transfer coefficient of $\mathrm{K}=0.035 \mathrm{~W} / \mathrm{m}^{\circ} \mathrm{K}$ and acrylic resin polymer plates coated with assembled aluminum panel sheet with a coefficient of thermal conductivity $\mathrm{K}=0.12 \mathrm{~W} / \mathrm{m}$ were used. ${ }^{\circ} \mathrm{K}$. (KUBIEC, sf).

Farfán, R. F. M., Zambrano, T. Y. M., Sosa, V. M. D., \& Zambrano, V. (2019). Design of eco-friendly refrigeration system. International Journal of Physical Sciences and Engineering, 3(2), 1-11. https://doi.org/10.29332/ijpse.v3n2.285 


\section{Verification Processes}

The testing procedure was carried out in the Unit of Research, Innovation and Technology Transfer of the Paulo Emilio Macías Higher Technological Institute, in 15 measurements at a variable interval of 8 hours, for 5 days. A PID controller TC-900E Log has used as a measuring instrument, with the following characteristics. In $\log 2$, the technical control specifications have shown. In Table 2.

Table 2

TC-900E controller technical specifications log

\begin{tabular}{ll}
\hline Description & Quantity \\
\hline Direct Supply & TC-900 Log: $115-230 \mathrm{Vac}+/-10 \%(50 / 60) \mathrm{Hz}$. \\
Control Operating & $-50^{\circ} \mathrm{C}$ to $105^{\circ} \mathrm{C} /-58^{\circ} \mathrm{F}$ to $221^{\circ} \mathrm{F}$ \\
Temperature & 0 to $50^{\circ} \mathrm{C} / 32$ to $122^{\circ} \mathrm{F}$ \\
Maximum Consumption of the Instrument & $1.5 \mathrm{VA}$ \\
Operating Humidity & 10 to $85 \%$ UR (without Condensation \\
Dimensions & $(76 \times 34 \times 77) \mathrm{mm}$ \\
\hline
\end{tabular}

Importance of storage and refrigeration of food

It is always necessary to know the products with which it is going to work and its importance, since, during its handling, preservation, and refrigeration, some characteristics Specific to these require special care related to temperature, relative humidity, among others, to name the food as tomato, they are initially green and change to characteristic tones of their variety as the chlorophyll decreases as they mature. On the breath, oxygen decreases $\left(\mathrm{O}_{2}\right)$ and increases carbon dioxide $\left(\mathrm{CO}_{2}\right)$ and ethylene, starch, soluble solids, and ascorbic acid. (HVACR, nd)

On the other hand, frozen fish do not have major problems and can be preserved for great quality times, if they are frozen and thaw well, on the tabla 1 the temperatures are collected in the case of frozen and refrigerated and the storage times. (M. \& C., 2002). Table 3 shows the conservation temperatures of fish and shellfish.

Table 3

Preservation temperatures of fish and shellfish

\begin{tabular}{lccc}
\hline Type of fish & $\begin{array}{c}\text { Temperature cooling } \\
\left({ }^{\circ} \mathrm{C}\right)\end{array}$ & $\begin{array}{c}\text { Frozen } \\
\text { Temperature }\left({ }^{\circ} \mathrm{C}\right)\end{array}$ & $\begin{array}{c}\text { Conservation } \\
\text { (days) }\end{array}$ \\
\hline Fatty & 0 to 2 & -18 & 120 \\
Lean & 0 to 2 & -18 & 240 \\
Plans & 0 to 2 & -18 & 270 \\
Mollusk & 0 to 2 & -18 & 120 \\
Crustaceans & 0 to 2 & -18 & 180 \\
\hline
\end{tabular}

Source: (Domínguez, M. and García, C., 2002)

In general, meat products are delicate and marketing in refrigeration mode it is short. Its conservation must be separated from those of other perishable products. Next, the conservation times in the refrigeration and freezing of the main types of meats, eggs, milk, and its derivatives have been collected, for the ideal conditions of conservation (Domínguez \& García, 1997). Table 4 shows the storage temperatures of meat, poultry, and milk. 
Table 4

Preservation temperatures of meat, poultry, and milk

\begin{tabular}{|c|c|c|c|c|c|}
\hline Producto & $\begin{array}{c}\text { Temperatura } \\
\text { Refrigeración } \\
\left({ }^{\circ} \mathrm{C}\right)\end{array}$ & $\begin{array}{l}\text { Humedad } \\
\text { relativa } \\
(\%)\end{array}$ & $\begin{array}{c}\text { Duración } \\
\text { conservada (días) }\end{array}$ & $\begin{array}{c}\text { Congelados } \\
\text { Temperatura } \\
\left({ }^{\circ} \mathrm{C}\right)\end{array}$ & $\begin{array}{c}\text { Duración } \\
\text { conservación } \\
\text { (días) }\end{array}$ \\
\hline Vaca & 0 a- 1,5 & 90 & 10 a 28 & $-18 \mathrm{a}-20$ & 365 \\
\hline Ternera & $-1,0$ & 90 & 7 a 21 & -18 a -20 & 300 \\
\hline Cordero & 1,0 & 90 a 95 & 7 a 14 & $-18 a-20$ & 270 \\
\hline Cerdo & $0,-1,5$ & 90 a 95 & 7 a 14 & -18 a -20 & 160 \\
\hline Tocino & $-3,-1$ & 80 a 90 & 30 & $-18 a-20$ & 90 \\
\hline Sebo & $-1,0$ & 80 a 95 & $90-150$ & $-18 a-20$ & 270 \\
\hline Manteca & $-1,0$ & 80 a 95 & $120-240$ & $-18 a-20$ & \\
\hline \multirow[t]{2}{*}{ Despojo } & $-1,0$ & 85 a 90 & 7 & $-18 a-20$ & \\
\hline & 0 a 2 & 85 a 90 & & $-18 a-20$ & \\
\hline \multicolumn{6}{|l|}{ Aves } \\
\hline Huevos & 0 a 1 & 85 a 90 & $160-190$ & & \\
\hline \multicolumn{6}{|l|}{ Leche } \\
\hline Normal & 0 a 4 & & & & \\
\hline Yogur & 2 a 5 & & 5 a 10 & & \\
\hline Esterilizada & 0 a 22 & & & & \\
\hline En polvo & 0 a 24 & & & & \\
\hline Evaporada & 5 & 60 a 70 & & & \\
\hline Nata & 0 a 2 & & & & \\
\hline Mantequilla & 4 a 6 & & 2 a 3 & & \\
\hline Quesos & & & 14 a 21 & $18 a-20$ & 240 \\
\hline Fresco & 0 a 5 & & & & \\
\hline Blandos & 0 a 2 & & 2 & & \\
\hline Duro & $0-5$ & & & & \\
\hline Fundido & 10 a 12 & 60 & & & \\
\hline Azules & 0 a 5 & & & & \\
\hline
\end{tabular}

Source: (Dominguez \& Garcia, 2002)

In another section the horticultural products are conserved very unequally in general, all with temperatures that vary to different ranges that were measured (Dominguez \& Garcia, 1997).

After having developed the experimental phase, it was demonstrated that refrigeration can be achieved from an air conditioning system, knowing that each one of those cited as a cold production service focuses the first one on preserving foods such as fruits, vegetables, liquids, and meat products, organs among others; and the air conditioning responds to the service of the comfort of the human being reaching ambient temperatures that are between $28^{\circ} \mathrm{C}$ to $17^{\circ} \mathrm{C}$ (air conditioning temperatures) and $28^{\circ} \mathrm{C}$ to $-13^{\circ} \mathrm{C}$ (freezing temperature), likewise we can detail that freezing results have been achieved from the redesign and optimal sizing. Table 5 shows the technical parameters of the operation of the freezing system.

Farfán, R. F. M., Zambrano, T. Y. M., Sosa, V. M. D., \& Zambrano, V. (2019). Design of eco-friendly refrigeration system. International Journal of Physical Sciences and Engineering, 3(2), 1-11. https://doi.org/10.29332/ijpse.v3n2.285 
Table 5

Technical parameters operating system freeze

\begin{tabular}{|c|c|c|c|c|c|c|c|c|c|c|c|c|c|c|}
\hline \multirow{2}{*}{ 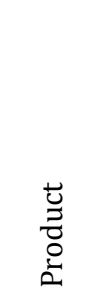 } & \multirow{2}{*}{ 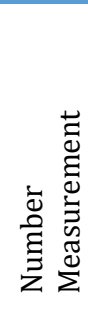 } & \multirow{2}{*}{ 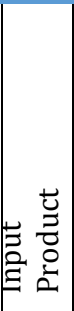 } & \multirow[t]{2}{*}{ 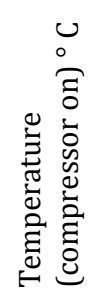 } & \multirow[t]{2}{*}{ 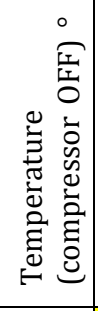 } & \multirow[t]{2}{*}{ 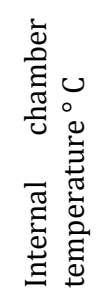 } & \multirow{2}{*}{ 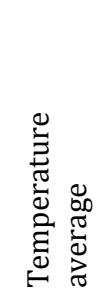 } & \multirow[b]{2}{*}{$\tilde{a}$} & \multirow[b]{2}{*}{$\tilde{b}$} & \multirow[t]{2}{*}{ 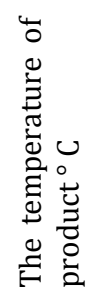 } & \multicolumn{2}{|c|}{ 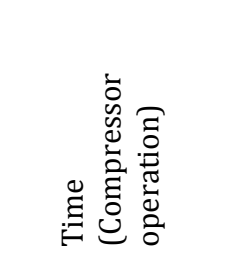 } & \multirow{2}{*}{ 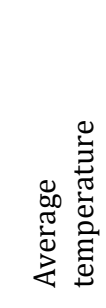 } & \multirow[b]{2}{*}{$\tilde{a}$} & \multirow[b]{2}{*}{$\tilde{6}$} \\
\hline & & & & & & & & & & On & Off & & & \\
\hline \multirow{5}{*}{ 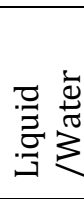 } & 1 & & 19.6 & $\begin{array}{l}-12 \\
\end{array}$ & -9.0 & \multirow{5}{*}{-8.00} & \multirow{5}{*}{3.58} & \multirow{5}{*}{0.00} & 0.4 & $17: 40$ & $17: 52$ & \multirow{5}{*}{-0.50} & \multirow{5}{*}{$\begin{array}{l}1 . \\
03\end{array}$} & \multirow{5}{*}{$\begin{array}{l}0 . \\
85\end{array}$} \\
\hline & 2 & & -10 & -12 & $\begin{array}{l}-9.8 \\
\end{array}$ & & & & 0.8 & $17: 54$ & $17: 58$ & & & \\
\hline & 3 & & -9.8 & $\begin{array}{l}-12 \\
\end{array}$ & -8.6 & & & & -1 & $17: 59$ & $18: 03$ & & & \\
\hline & 4 & & -10 & -12 & -8 & & & & -1.2 & $18: 05$ & 18:08 & & & \\
\hline & 5 & & -10 & -12 & -7.7 & & & & -1.5 & $18: 10$ & $18: 13$ & & & \\
\hline \multirow{5}{*}{$\begin{array}{l}\frac{0}{0} \\
\frac{\pi}{0} \\
0 \\
0 \\
0 \\
0\end{array}$} & 1 & & 19.6 & $\begin{array}{l}-12 \\
\end{array}$ & $\begin{array}{l}-7.9 \\
\end{array}$ & \multirow{5}{*}{-7.80} & \multirow{5}{*}{3.18} & \multirow{5}{*}{0.00} & 4 & $17: 31$ & $17: 41$ & \multirow{5}{*}{3.5} & \multirow{5}{*}{$\begin{array}{l}1 . \\
95\end{array}$} & \multirow{5}{*}{$\begin{array}{l}0 . \\
25\end{array}$} \\
\hline & 2 & & -10 & -12 & -7.8 & & & & 3 & $17: 42$ & $17: 46$ & & & \\
\hline & 3 & & -10 & -12 & -7.7 & & & & 1.8 & $17: 53$ & $17: 57$ & & & \\
\hline & 4 & & -10 & & $\begin{array}{l}-7.6 \\
\end{array}$ & & & & -0.5 & & & & & \\
\hline & 5 & & -10 & & $\begin{array}{l}-7.7 \\
\end{array}$ & & & & -1.5 & & & & & \\
\hline \multirow{5}{*}{ 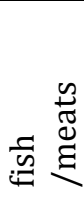 } & 1 & & 21.8 & & -8.2 & & & & 4 & 13h51 & $14 \mathrm{~h} 57$ & \multirow{5}{*}{0.22} & \multirow{5}{*}{$\begin{array}{l}3 . \\
21\end{array}$} & \multirow{5}{*}{$\begin{array}{l}8 . \\
23\end{array}$} \\
\hline & 2 & & -10 & -12 & -6 & & & & 2.1 & $14: 59$ & $15: 05$ & & & \\
\hline & 3 & & -10 & -12 & -8.0 & & & & 1 & 15:06 & $15: 15: 13$ & & & \\
\hline & 4 & & -10 & -12 & -8.7 & & & & -2 & $15: 15$ & $15: 22$ & & & \\
\hline & 5 & & -10 & -12 & -9.2 & & & & -4 & $15: 25$ & $15: 32$ & & & \\
\hline
\end{tabular}

Fuente: Muñoz, R.; Macías, T.; Delgado, V. y Zambrano, V.

Table 6 shows the average temperature and standard deviation results.

Table 6

Temperature chamber and products (liquids) in chamber

\begin{tabular}{|c|c|c|c|c|}
\hline Data & Temperature & Varies & Media & Trap \\
\hline 1 & -9 & 0.25 & $-8,5$ & 4.67 \\
\hline 2 & -9.8 & 0.25 & -8.5 & 4.67 \\
\hline 3 & -8.6 & 0.25 & -8.5 & 4.67 \\
\hline 4 & -8 & 0.25 & -8.5 & 4.67 \\
\hline 5 & -7.7 & 0.25 & -8.5 & 4.67 \\
\hline
\end{tabular}

The graph of Figure 1 shows the chamber temperature and liquid products.

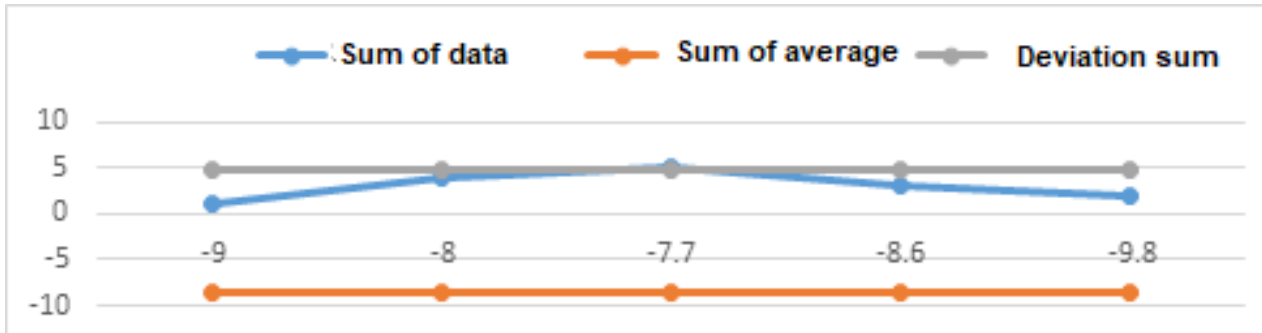

Figure 1. Chamber temperature and products (liquids)

The graph in Figure 2 shows temperature and liquid products. 


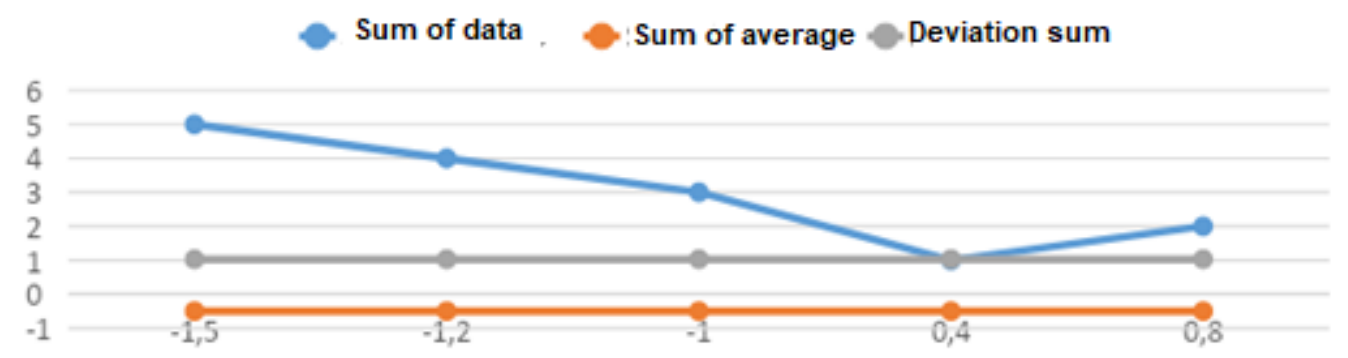

Figure 2. Product-liquid temperature

As part of the results, liquid products have a freezing presence in approximately 20 minutes, starting from the first phase of turning the compressor on and off, reaching the internal temperature of the chamber. $8.53{ }^{\circ} \mathrm{C}$, with its standard deviation of $4.67^{\circ} \mathrm{C}$, likewise records an average temperature of the liquid product of $-0.5^{\circ}$ $\mathrm{C}$ and its standard deviation of $1.03^{\circ} \mathrm{C}$. The graph of Figure 3 shows the temperature of the Chamber and Products (Vegetables) in the chamber

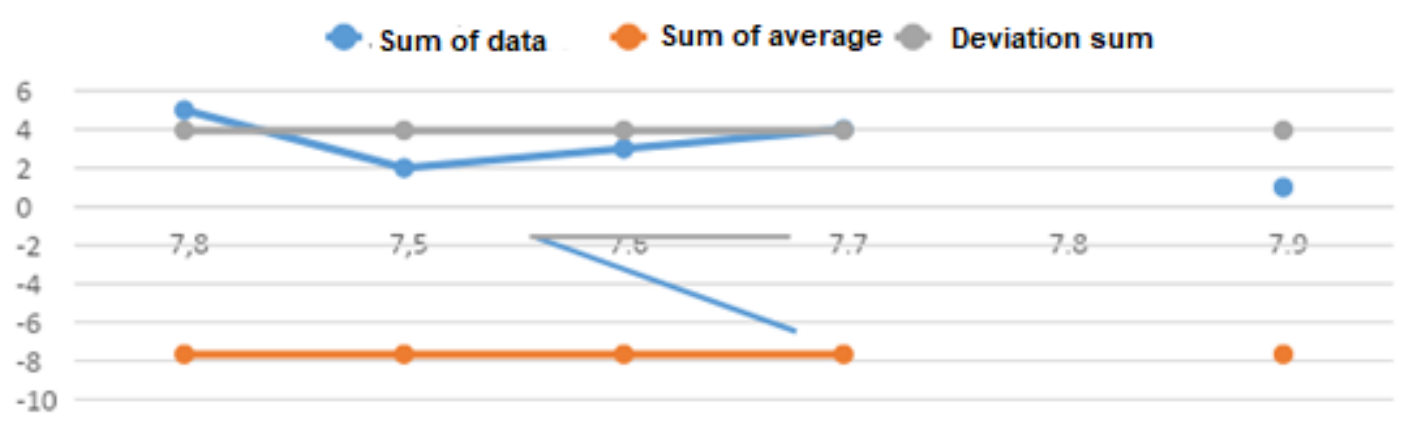

Figure 3. Internal chamber temperature vegetables

Figure 4 shows the internal temperature of the product-vegetable.

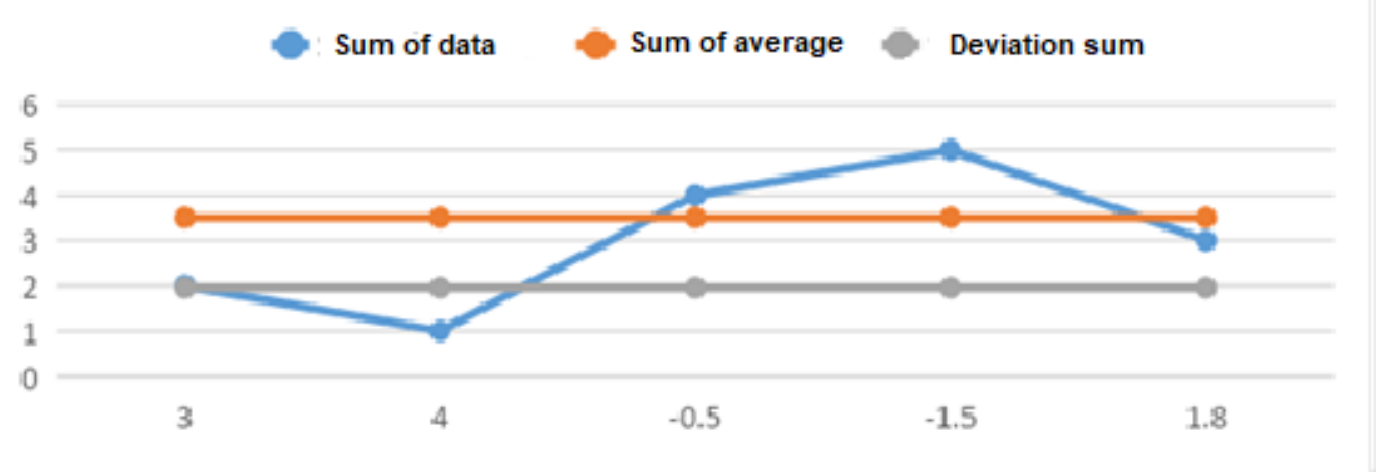

Figure 4. The internal temperature of the product - vegetables

According to the present statistical tables we show that in products such as vegetables it is in the presence of preservation approximately in $20 \mathrm{~min}$, from the first phase of ignition and shutdown of the compressor

Farfán, R. F. M., Zambrano, T. Y. M., Sosa, V. M. D., \& Zambrano, V. (2019). Design of eco-friendly refrigeration system. International Journal of Physical Sciences and Engineering, 3(2), 1-11. https://doi.org/10.29332/ijpse.v3n2.285 
reaching the internal temperature of camera of $-7.8^{\circ} \mathrm{C}$ with its standard deviation of $3.18^{\circ} \mathrm{C}$, likewise records an average vegetable product temperature of $3.5^{\circ} \mathrm{C}$ and its standard deviation of $1.95^{\circ} \mathrm{C}$ as shown in figure 5

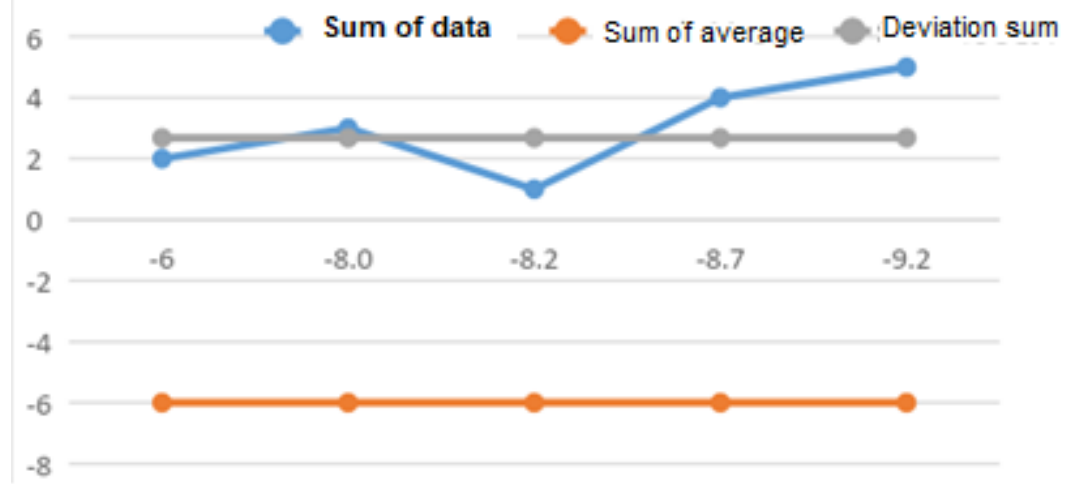

Figure 5. Temperature internal chamber-meat products

Figure 6 shows the internal temperature of the chamber for the preservation of meat products.

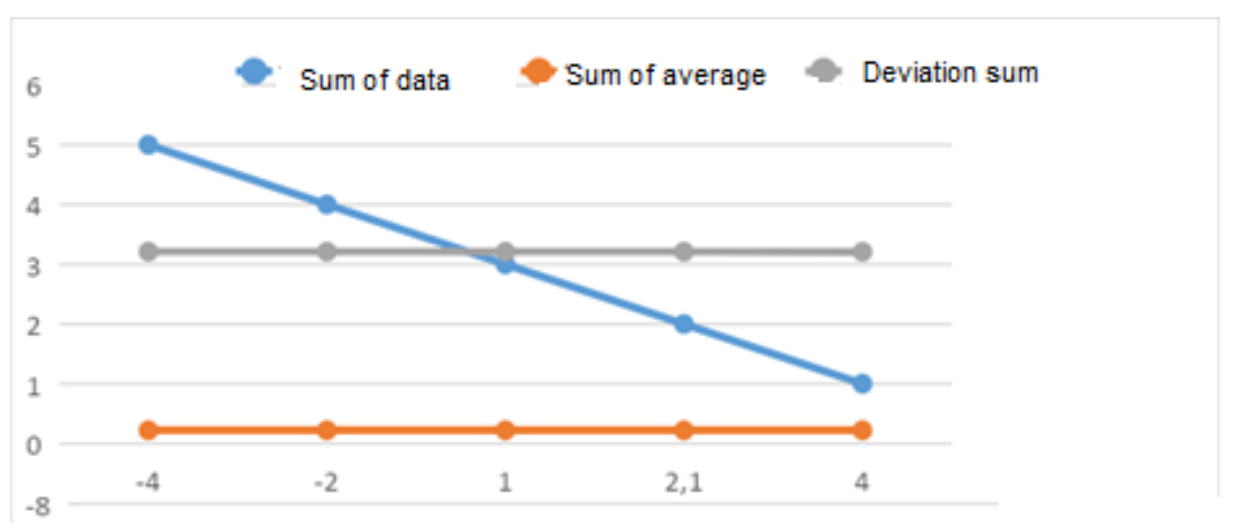

Figure 6. The internal temperature of the chamber for meat preservation

As a result it was found that in meat products/fish it is in the presence of preservation approximately in 40 min, from the first phase of ignition and shutdown of the compressor reaching the internal chamber temperature of $-6^{\circ} \mathrm{C}$ with its standard deviation of $2.68^{\circ} \mathrm{C}$., Likewise records an average meat/fish product temperature of $0.22^{\circ} \mathrm{C}$ and its standard deviation of $3.21^{\circ} \mathrm{C}$.

Product of the experimentation, in liquid products there is freezing presence approximately in 20 min, from the first phase of turning the compressor on and off reaching the average internal chamber temperature of $-8.53^{\circ} \mathrm{C}$, with its standard deviation of $4.67^{\circ} \mathrm{C}$., likewise records an average temperature of liquid product of $-0.5^{\circ} \mathrm{C}$ and its standard deviation of $1.03^{\circ} \mathrm{C}$. Contrasting the results with those of (Maury et al., 2010) who analyzed several samples of breast milk at a temperature of $-20^{\circ} \mathrm{C}$ in terms of Its protein quality and storage time could be reached up to 90 days while preserving its properties.

In products such as vegetables, conservation begins in about 20 minutes, starting with the first phase of turning the compressor on and off, reaching the internal chamber temperature of $-7.8^{\circ} \mathrm{C}$ with its standard deviation of $3.18^{\circ} \mathrm{C}$. It also registers a temperature average vegetable product of $3.5^{\circ} \mathrm{C}$ and its standard deviation of $1.95^{\circ} \mathrm{C}$. In a study of (García \& Pacheco, 2007) two morphs of celery were stored, yellow and white at a temperature of $10^{\circ} \mathrm{C}$, obtaining results of not susceptibility to cold, maintaining physical characteristics for 5 days with average weight loss in white celery of $13.73 \mathrm{~g}$ water/100 $\mathrm{g}$ and in the yellow of $17.65 \mathrm{~g}$ water $/ 100 \mathrm{~g}$.

In meat/fish products the conservation takes approximately 40 minutes, starting from the first phase of turning the compressor on and off, reaching the internal chamber temperature of $-6^{\circ} \mathrm{C}$ with its standard 
deviation of $2.68^{\circ} \mathrm{C}$. an average meat/fish product temperature of $0.22^{\circ} \mathrm{C}$ and its standard deviation of $3.21^{\circ}$ C. In the study of (Milagros et al., 2006) samples of flying fish were stored in a chamber of domestic type at -18 ${ }^{\circ} \mathrm{C}$ for ninety-five days, estimated time of life in storage according to previous tests carried out by the crew of the vessel that supplied the fish. On the other hand, despite the fact that the final product was frozen twice, one at sea and another in the tray fillet mode, no signs of deterioration were observed, since rapid freezing methods were used in both processes. In addition, thawing before filleting was performed at a low temperature $\left(-18^{\circ} \mathrm{C}\right)$, in order to avoid excessive dripping.

\section{Conclusion}

A refrigeration system was designed and evaluated for different products, noting that it is possible to use it being sustainable in areas where today many of the food products do not have any type of conservation.

\section{Acknowledgments}

Special recognition is given to all the personnel that works to achieve the evaluation of sustainable refrigerator.

Farfán, R. F. M., Zambrano, T. Y. M., Sosa, V. M. D., \& Zambrano, V. (2019). Design of eco-friendly refrigeration system. International Journal of Physical Sciences and Engineering, 3(2), 1-11. https://doi.org/10.29332/ijpse.v3n2.285 


\section{References}

Belvinel, E.-T. G., Loor, G. A., Chilan, J. C. H., \& Gamez, M. R. (2018). Photovoltaic system implementation in baltra and puerto ayora islands. International Journal of Life Sciences,2(3), 20-27. https://doi.org/10.29332/ijls.v2n3.200

Domínguez, M. \& García, C. (1997). The cold and storage conditions. Instal Noticias, 23-28.

Domínguez, M. \& García, C. (2002). The controlled temperature distribution of perishable products in Europe. Food No. 169. Institute of the cold, 45-48.

García, A. \& Pacheco, E. (2007). Effect of temperature on the post-harvest quality of Creole celery. Tropical Agronomy, 57(4), 45-56.

Ghosh, C. (2017). A study on - evaluating marketing strategies adopted by home appliance for economic development in India. International Journal of Social Sciences and Humanities, 1(1), 9-15. https://doi.org/10.29332/ijssh.v1n1.7

HVACR, M. (nd). WORLD HVACR. Retrieved from https: www.mundohvacr.com.mx/

Iriarte Rota, MM, González, R., \& del Valle, G. (2006). Effect of storage time at -18으 on the bacteriological and physico-chemical characteristics of flying fish fillets (Dactylopterus volitans). Scientific Journal , 16 (2), 195-201.

KUBIEC, NQ (nd). Kubiec, more than a steel. Retrieved from https://kubiec.com/

M., I. d., \& C., G. (2002). The controlled temperature distribution of perishable products in Europe.

Maury, E., Sequera, S., Sanchez, D., Bravo, A., Romero, M., \& Vizcarra, M. (2010). Changes in Protein Composition of Mature Breast Milk during Storage by Freezing. Pediatrics (Asunción) , 37 (3), $187-194$.

Mittal, AG (nd). ACINDAR Grupo Acrcelor Mittal. Retrieved from http:www.acindar.com.ar/

National Assembly (2013). National Plan for Good Living 2013-2017. Quito: Senplades.

Omer, A. M. (2015). Performance, modeling, measurements, and simulation of energy efficient for heat exchanger, refrigeration and air conditioning. International Research Journal of Engineering, IT \& Scientific Research, 1(1), 24-44. Retrieved from https://sloap.org/journals/index.php/irjeis/article/view/235 


\section{Biography of Authors}

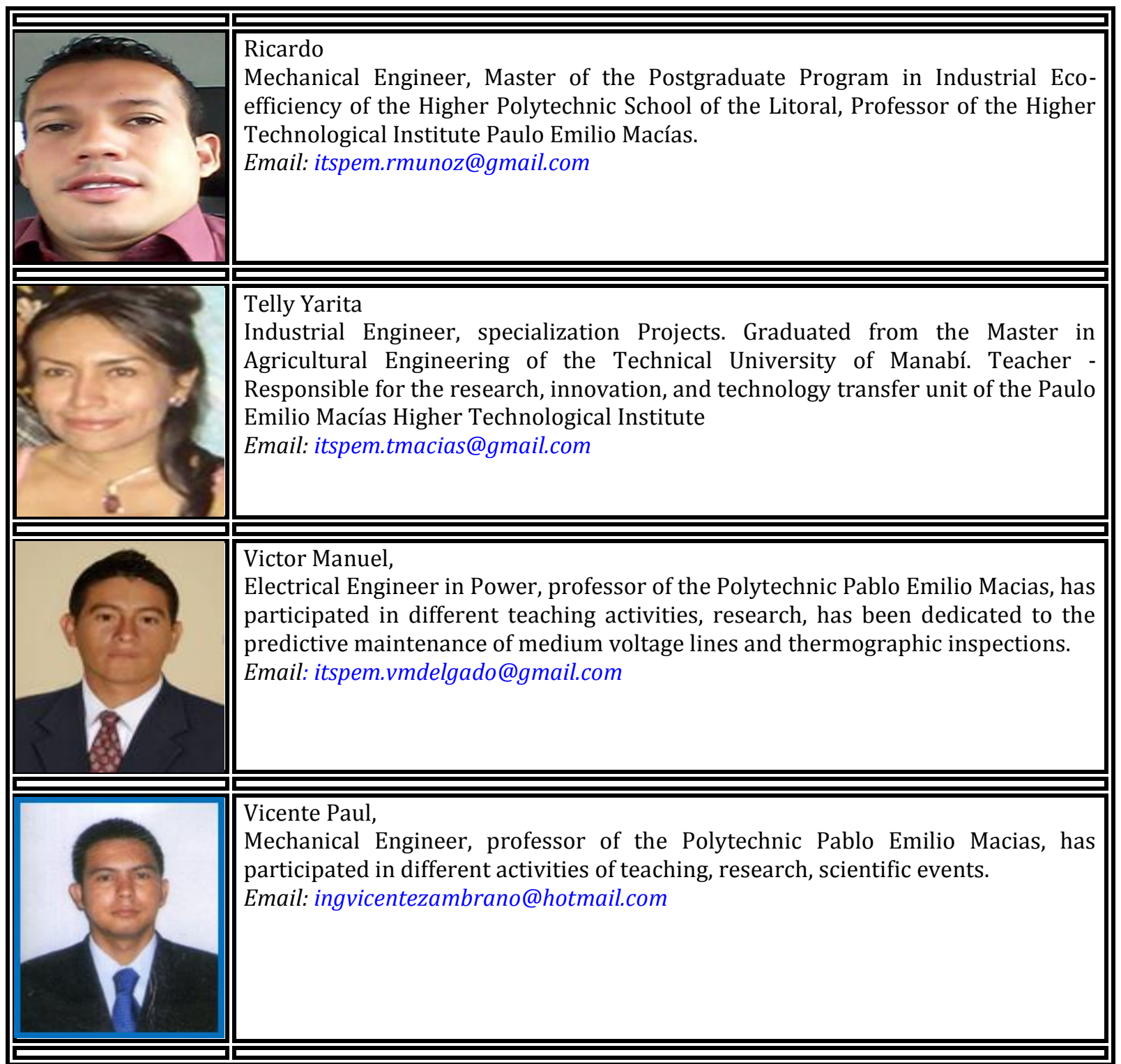

Farfán, R. F. M., Zambrano, T. Y. M., Sosa, V. M. D., \& Zambrano, V. (2019). Design of eco-friendly refrigeration system. International Journal of Physical Sciences and Engineering, 3(2), 1-11. https://doi.org/10.29332/ijpse.v3n2.285 